The Myth of Elizabeth 
Related titles by Palgrave Macmillan

Paul Hammer, ELIZABETH'S WARS

Carole Levin, THE REIGN OF ELIZABETH I

A. L. Rowse, THE ENGLAND OF ELIZABETH

A. L. Rowse, THE EXPANSION OF ELIZABETHAN ENGLAND Julia Walker, ELIZABETH I AS ICON 


\section{The Myth of Elizabeth}

Edited by

SUSAN DORAN AND THOMAS S. FREEMAN 


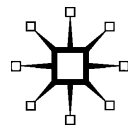

Selection, editorial matter and Introduction

(C) Susan Doran and Thomas S. Freeman 2003

Individual chapters (in order) (c) Thomas S. Freeman; Andrew Hadfield;

Patrick Collinson; Lisa Richardson; Teresa Grant; Alexandra Walsham;

Susan Doran; Brett Usher; Jason Scott-Warren; Thomas Betteridge 2003

All rights reserved. No reproduction, copy or transmission of this publication may be made without written permission.

No paragraph of this publication may be reproduced, copied or transmitted save with written permission or in accordance with the provisions of the Copyright, Designs and Patents Act 1988, or under the terms of any licence permitting limited copying issued by the Copyright Licensing Agency, 90 Tottenham Court Road, London W1T 4LP.

Any person who does any unauthorised act in relation to this publication may be liable to criminal prosecution and civil claims for damages.

The authors have asserted their rights to be identified as the authors of this work in accordance with the Copyright, Designs and Patents Act 1988.

First published 2003 by

PALGRAVE MACMILLAN

Houndmills, Basingstoke, Hampshire RG21 6XS and

175 Fifth Avenue, New York, N.Y. 10010

Companies and representatives throughout the world

PALGRAVE MACMILLAN is the global academic imprint of the Palgrave Macmillan division of St. Martin's Press, LLC and of Palgrave Macmillan Ltd. Macmillan ${ }^{\circledR}$ is a registered trademark in the United States, United Kingdom and other countries. Palgrave is a registered trademark in the European Union and other countries.

ISBN 978-0-333-93083-0 hardback

ISBN 978-0-333-93084-7 DOI 10.1007/978-0-230-21415-6

ISBN 978-0-230-21415-6 (eBook)

This book is printed on paper suitable for recycling and made from fully managed and sustained forest sources.

A catalogue record for this book is available from the British Library.

A catalogue record for this book is available from the Library of Congress.

$\begin{array}{llllllllll}10 & 9 & 8 & 7 & 6 & 5 & 4 & 3 & 2 & 1\end{array}$

$\begin{array}{llllllllll}12 & 11 & 10 & 09 & 08 & 07 & 06 & 05 & 04 & 03\end{array}$ 


\section{Contents}

List of illustrations vii

Acknowledgements viii

Introduction 1

Thomas S. Freeman and Susan Doran

PART 1

TROJAN HORSES: CONTEMPORARY CRITICISMS OF ELIZABETH

1 Providence and Prescription: The Account of Elizabeth in Foxe's 'Book of Martyrs'

Thomas S. Freeman

2 Duessa's Trial and Elizabeth's Error: Judging Elizabeth in Spenser's Fairie Queene

Andrew Hadfield

PART 2

JACOBEAN PERSPECTIVES: POLITIC PRINCESS OR PROTESTANT HEROINE?

3 William Camden and the Anti-Myth of Elizabeth: Setting the Mould?

Patrick Collinson

4 Elizabeth in Arcadia: Fulke Greville and John Hayward's

Construction of Elizabeth, 1610-12

Lisa Richardson

5 Drama Queen: Staging Elizabeth in If You Know Not Me

You Know Nobody

Teresa Grant 
6 'A Very Deborah?' The Myth of Elizabeth I as a Providential Monarch Alexandra Walsham

PART 3

ELIZABETH ENGENDERED: PRESENTATION AND PRACTICE

7 Virginity, Divinity and Power: The Portraits of Elizabeth I 171 Susan Doran

8 Queen Elizabeth and Mrs Bishop Brett Usher

9 Harington's Gossip Jason Scott-Warren

10 A Queen for All Seasons: Elizabeth I on Film Thomas Betteridge

List of Abbreviations

Notes on the Contributors

Index 


\section{List of Illustrations}

1 Elizabeth as Europa

2 'The night of Popish superstition' and 'The returne of the Gospells light', Crumms of Comfort

3 Thomas Cecil, Elizabeth Angliae et Hiberniae Reginae \& c. 160

4 John Dassier's late eighteenth-century medal of Elizabeth I with the Armada, the eye of Providence, the Bible and the lighted candlestick of the Gospel

5 The initial C from John Foxe, Acts and Monuments

6 Hans Eworth, Elizabeth I and The Three Goddesses

7 Crispin Van de Passe, Queen Elizabeth I

8 Thomas Bentley's The Monument of Matrones Conteining Seuen Seueral Lamps of Virginitie

9 Bette Davis as Elizabeth I in The Private Lives of Elizabeth and Essex

10 Cate Blanchett as Elizabeth I in Elizabeth 


\section{Acknowledgements}

The editors and publishers wish to thank the following for permission to use copyright material:

The Ashmolean Museum, Oxford, for use of the image Elizabeth as Europa (1598) from the Sutherland Collection. Reproduced by permission of the Ashmolean Museum.

Bodleian Library, University of Oxford, for use of the engraving opposite page 362 from The Monument of Matrones Conteining Seuen Seuerall Lamps of Virginitie by Thomas Bentley (1528). Reference (shelf mark) $4^{\circ}$ C 38 Jur. Reproduced by permission of the Bodleian Library, University of Oxford.

The British Library for use of the image 'The night of Popish superstition' and 'The returne of the Gospells light' from Michael Sparke, Crumms of Comfort (1628 edn). British Library classmark C.65.7(2). Reproduced by permission of the British Library.

The British Museum for use of the following images: Thomas Cecil, Elizabeth Angliae et Hiberniae Reginae \& c. (1625); John Dassier's late eighteenth-century medal of Elizabeth I with the Armada, the eye of Providence, the Bible and the lighted candlestick of the Gospel; Crispin Van de Passe, Queen Elizabeth I. All images (C) copyright The British Museum.

The Dean and Chapter of York for use of the image the initial C from John Foxe, Acts and Monuments (1569) (YML ref: 11.B.9). Reproduced by kind permission of the Dean and Chapter of York.

The Kobal Collection for use of the following images: Cate Blanchett in Elizabeth (Polygram); Bette Davis in The Private Lives of Elizabeth and Essex (Warner Bros/First National). Both images reproduced courtesy of the Kobal Collection.

The Royal Collection Enterprises for use of the image Elizabeth I and the Three Goddesses by Hans Eworth (1520-1574?). The Royal Collection (C) 2001, Her Majesty Queen Elizabeth II. Reproduced courtesy of The Royal Collection. 
Every effort has been made to trace the copyright holders but if any have been inadvertently overlooked, the publishers will be pleased to make the necessary arrangement at the first opportunity. 